\title{
Ballot Design and Invalid Votes: Evidence from Colombia ${ }^{1}$
}

\author{
Mónica Pachón \\ Dean \\ School of Political Science, Government and International Relations \\ Universidad del Rosario \\ Calle 12 \# 6C- 25, Edificio Santa Fé, Segundo Piso \\ Bogotá, Colombia \\ monica.pachonb@urosario.edu.co \\ Royce Carroll \\ Reader in Comparative Politics \\ Department of Government \\ University of Essex \\ Wivenhoe Park, Colchester CO4 3SQ \\ United Kingdom \\ r.carroll@essex.ac.uk \\ Hernando Barragán \\ Dean \\ School of Architecture and Design \\ Universidad de los Andes \\ Carrera 1 \# 18A - 12 \\ Bogotá, Colombia \\ hbarragan@uniandes.edu.co
}

\footnotetext{
${ }^{1}$ We would like to thank the International Republican Institute and USAID to help fund this project, and the team of the National Registar's Office for their interest and team work in the design and implementation of the 2011 ballot for the local elections in Colombia. Especially, we would like to thank Carlos Ariel Sánchez, former National Registar, as well as Alfonso Portela, for their significant help and interest every step of the process. We would also like to thank Ana Vélez and Congreso Visible's team at Universidad de los Andes (www.congresovisible.org).

Finally, we would like to thank Andrés Felipe Jacobo, Maria Paula Barón, Santiago Lacouture and Santiago Mateo Villamizar for their research assistance in this project.
} 


\begin{abstract}
We examine the tendency for complex ballot tasks to undermine the ability of votes to cast valid ballots. Specifically, we investigate whether ballot design is responsible for the high rate of spoiled ballots in Colombia in 2007. We address this question first by looking at data from a study observing the use of alternate ballot designs in a controlled environment, varying the information voters have when attempting to cast the ballot. We then examine the observed pattern of spoiled ballots in Colombia before and after the implementation of the ballot redesign tested in an experiment conducted in Bogotá. Our results show that there is an independent effect of the ballot design on the amount of spoiled ballots and that this effect correlates with certain selfreported socio-demographic characteristics such as education. We also demonstrate that by improving the usability of the ballot the number of spoiled ballots drops significantly and the effect of socio-demographic variables become less important in explaining the presence of spoiled ballots. Also, aggregate results of the 2011 local elections at the municipal elections show a significant drop in spoiled ballots.
\end{abstract}




\section{Ballot Design and Invalid Votes: Evidence from Colombia}

\section{Introduction}

While scholars of elections normally focus on voter choices and participation, an important amount of variation in electoral outcomes results from forms of unrecorded or "residual" votes, where the choices of participating voters are excluded from the electoral count. Some of these are

"overvotes," where a voter makes additional marks that exceed the maximum allowed. Others are "undervotes," where a voter fails to mark some aspect of the ballot. When ballots are improperly marked in some way, they are typically considered rejected ballots and not counted, regardless of voter intent. These invalid votes can be highly consequential, especially in close elections such as that in the 2000 election in the US (Mebane 2004, Kimball et al. 2004, Leib and Dittmer 2002, Bullock et al. 2002) and can amount to very large numbers of votes, as in the Scottish 2007 election (Carman et al. 2008). The Institute for Democracy and Electoral Assistance reports that, among countries rated 4 or lower by Freedom House, 53 countries had at least one election with invalid votes exceeding 5\% and 24 countries had at least one election exceeding $10 \%$. When rejected ballots render invalid votes actually intended to be cast and occur in significant numbers, they can be especially harmful to the legitimacy of elections.

Partly due to the tendency of these patterns to emerge in democracies facing questions of electoral legitimacy (Uggla 2008), many scholars have shown that invalid votes can be deliberate political acts, serving as a form of protest against a government or expression of apathy (Steifbold 1965, Zulfikarpasic 2001, Power and Garand 2007, Uggla 2008, Aldashev and Mastrobuoni 2010, Superti 2016, Moral 2016, Alvarez et al. 2016). Invalid votes might therefore reflect voters spoiling their ballots as a means to intentionally express dissatisfaction with the options available to them, perhaps due to a perceived lack of competition or meaningful choices.

However, a considerable amount of research suggests that invalid votes, even on a large scale, can result from voter error owing to the ballot design and usability (Power and Roberts 1995, Carman et al 2008, Taylor 2012, Kimball and Kropf 2005, Leib and Dittmer 2002, Traugott et al 2005, Hanmer et al. 2010, Herrnson et al 2012, Herron and Sekhon 2003) especially in the context of certain voter characteristics (McAllister and Makkai 1993, Kimball and Kropf 2005, Tomz and Van Houweling 2003, Neely and Cook 2008, Buchler et al. 2004). While the comparative study of electoral systems mostly focuses on basic differences in vote allocation methods, each system also provides a wide array of ballot variations. Ballot designs have an impact on the information burden and general complexity faced by citizens (Bonneau and Loepp 2014, Katz et al. 2010). Yet, outside of the United States, very little scholarly attention has been paid to the vast differences possible in the designs of ballots that affect the complexity of indicating voter intent, even within the same electoral system. 
One of the most important consequences of variations in voting technology is the effect on usability--how successfully voter intent is correctly understood. The information burden generated by the ballot may be pivotal by not providing sufficient cues in ballot design to translate voter preferences into informed choices. Meanwhile, voters themselves will vary in their levels of information about the electoral process in general, which in turn influences how important these cues are to behavior. The challenge in understanding the relationship between these factors is the difficulty in capturing both these concepts.

One case in which we can obtain analytical leverage on these questions is that of Colombia. In Colombia's 2006 and 2010 elections, invalid votes amounted to over $13 \%$ of total votes, among the highest rates in the world. Colombia is a useful case for analyzing the effects of ballot design on invalid votes because it has used two very different ballots with the same electoral system and because the rate of invalid votes has been considerable. In this paper, we investigate the role of ballot design in explaining the high rate of invalid votes in Colombia. We address this question first by looking at data from a study observing the use of alternate ballot designs in a controlled environment, varying the information voters have when attempting to cast the ballot. We then examine the observed pattern of invalid votes in Colombia before and after the implementation of a ballot redesign.

Our results show that there is an independent effect of the ballot design on the amount of invalid votes and that the magnitude of this effect varies with self-reported socio-demographic characteristics. We also demonstrate that by improving the usability of the ballot, the number of rejected ballots drops significantly and the effect of voter characteristics is less apparent as an explanatory factor. We find a similar pattern in the observed electoral data when comparing the two elections.

\section{Explaining invalid votes}

Some scholars have suggested that invalid votes are sometimes political acts, protesting the election itself. For example, a number of early studies on this topic suggested that in systems of compulsory voting, invalid ballots provide the equivalent of abstention. In line with this reasoning, Power and Garand (2007) show that in countries with compulsory voting, there is a greater percentage of rejected ballots as voters use the act to vote as an opportunity to protest against the regime. Countries without compulsory voting may instead have lower levels of participation, rather than a substantial percentage of rejected ballots. Even in contexts without compulsory voting, it is plausible that voters would make the effort to vote and then intentionally spoil their ballot as part of a political statement.

However, in other cases, research suggests that invalid votes, even on a large scale, can result from voter error owing to the ballot design and its usability. One part of this is the information burden generated by the ballot or the political sophistication of the voter. The first aspect can be thought of as an institutional factor: are sufficient cues provided by ballot design to translate 
voter preferences into informed choices? An array of research has shown that the type of ballot matters for political outcomes (Alvarez et.al. 2004, 2009; Sinclair and Alvarez 2004, Herrnson et. al, 2008, 2012; Carman et al. 2008, Calvo et al., 2009, Katz et al. 2010). For example, Reynolds and Steenberg (2006) show that the use of colors, pictures and symbols might affect the use of the ballot. Bonneau and Loepp (2014) present evidence that the use of party logos increases voting for "down ballot" races, as there are more cues voters can rely on. Another example can be found in Matson and Fine (2006), who found that the positioning of candidates and offices within the same ballot can affect participation in those races. Kimball and Kropf (2005) perform a large-scale study of US ballot designs and show a systematic relationship with the patterns of unrecorded votes.

Another aspect of this question regards the characteristics of voters themselves - such as their levels of information and/or degree of political sophistication - which can increase the importance of clear instructions and cues on ballots. McAllister and Makkai (1993), for instance, find that Australian invalid votes are a result not of protest, but of the linguistic difficulty faced by certain populations. Kimball and Kropf (2005) for instance, find that invalid votes in US presidential elections are related to disparities in ballot design. Moreover, US scholars have often found that ballot design regulates whether demographic features correlate with rejected ballots (Tomz and Van Houweling 2003, Kimball and Kropf 2005, Knack and Kropf, 2003; Sinclair and Alvarez, 2004). In Brazil, Power and Roberts (1995) argue that "open list" ballots in particular where individual candidates are selected from party lists - can be problematic as they may demand higher levels of sophistication and information from voters. Open lists require voters to evaluate ballots with choices to cast a vote for an individual across many lists of candidates from various parties. These lists are as big as the number of available seats in the district. With a high number of seats in districts (district magnitude), as in Colombia, open lists especially increase the potential for complexity, especially among voters with lower levels of political information, interest or sophistication.

\section{Electoral and Ballot Reform in Colombia}

The electoral ballot in Colombia, prepared by the electoral National Civil Registry ${ }^{2}$, was first introduced in Colombia in the late $1980 \mathrm{~s}^{3}$ and was amended twice after approval of the 2003 Political Reform ${ }^{4}$, which instituted the option for parties to use open list proportional representation, where voters rank candidates and seats are assigned within parties based on those ranks. Prior to the reform, Colombia employed a nominally closed list system that, in practice, functioned as a "personal list" system (Carey and Shugart 1995), analogous to individual

\footnotetext{
${ }^{2}$ This function is performed by the Registrar's Office for Electoral Processes.

${ }^{3}$ Prior to this era, ballots were provided directly by parties, rather than administered by the government. See Taylor (2012) for a detailed history of Colombian ballots.

${ }^{4}$ Legislative Act 01 of 2003.
} 
candidates running in districts alone under de facto plurality rules. Reinforcing the emphasis on personalism during this era, the ballot design depicted the photos and names of all candidates without differentiating by parties or type of district (the reserved seats in Congress for indigenous movements or Afro-Colombian descendants). The first 2003 ballot design for local elections removed the pictures, kept the names, and organized candidates by party affiliation, shown in Figure 1. In the first election after the reform, the percentage of rejected ballots was largely unchanged, at 4-5\% (Registraduría Nacional del Estado Civil). Nonetheless, keeping the entire candidate name on the ballot was considered nonviable for national elections for the considerably larger number of candidates in the Senate and House, and the existence of multiple districts.

For the 2006 national elections, a new ballot design was implemented that included two sections: one with party logos and names, and another with numbers that were assigned to each candidate, and removed the names of candidates. Voters would have to memorize the party logo and name as well as the number of the candidate within the party list in order to vote effectively. This design is shown in Figure 2. ${ }^{5}$

Figure 2 about here

In the subsequent elections, there was a dramatic increase in rejected ballots. Nationally, the percentage of invalid votes for the election of House was $4.23 \%$ in 2002 , then $13.12 \%$ in 2006 and finally $14.4 \%$ in 2010 . This allowed many to question the legitimacy of the elections, as about a tenth of the votes across the country were considered invalid.

To determine whether ballot design - rather than protest behavior or intrinsic properties of the "open list" electoral system itself - was responsible for these patterns, we coordinated with the National Registry to conduct a study to assess the usability of the ballot in comparison to alternative designs. First, we sought to analyze a random sample of the votes for the Council of Bogotá in 2007. Second, we conducted a study in Bogotá allowing subjects to simulate use of a new ballot designed to correct problems found in the 2007 election. We first report on the results of this analysis and then compare these findings to the subsequent use of the ballot in practice in local council elections.

\section{Patterns of rejected ballots: The Bogotá Municipal Council Elections 2007}

Our first concern was to clarify the types errors made in practice in 2007. Did invalid ballots appear to be attempts to indicate a preference or deliberate attempts to protest the election? To get at this question, we first obtained permission to examine a random sample of 18,278 ballots that were cast in the elections for the Council of Bogotá in 2007, which used the design shown in

\footnotetext{
${ }^{5}$ Note that the ballot was divided the department level constituencies and minority seats elected via a national constituency. For the local elections discussed below, there would be only one district per ballot.
} 
Figure 3.

Figure 3 about here

Here we can observe actual votes, which allows us to differentiate between "types" of invalid votes. Among these were 1362 invalid votes - a rate of $7.48 \%$, which is close to that reported for the entire set for this council--7.27\%. This sample was chosen randomly and produced the results in Table 1.

Table 1 about here

The Table highlights two groups of factors driving rejected ballots. The first group corresponding to row 1 shows that the most common voting error was choosing a candidate without choosing a party: $71.15 \%$ of cases. These voters likely intended to cast a ballot for a candidate. The second most common group involved potentially deliberate efforts at invalidating the ballot, either by making an invalid mark or by marking several parties. This behavior accounted for $18.8 \%$ of the ballots rendered invalid in the sample. Only $4.70 \%$ of the rejected ballots in the sample clearly spoil the ballot by marking all areas of the ballot or just using the ballot clearly to express their discontent. This sample also included another form of residual vote that is clearly an intentional protest, the "blank vote" that represents an explicit "none of the above" option. In this sample, the percentage of blank votes per locality was $12.36 \%$.

The patterns observed in this sample of cast ballots suggest that most rejected ballots probably resulted from unintentional errors. This pattern may suggest that many citizens treated the ballot similarly to the earlier candidate-only electoral system, despite the ballot and rule changes. This tendency to continue such behavior in the face of the new system suggests that the ballot failed to clarify the process of selecting choices to translate voter preferences. ${ }^{6}$

Because of the potential for usability problems, the Registraduría agreed to pilot an alternative ballot. This ballot, shown in Figure 4a, created a separate area for each party presenting candidates in the district instead of two separate sections for parties and candidate numbers, as was the case in the 2007 and 2010 elections. This eliminated the need to mark two separate areas or to have the same set of identifying numbers for candidates of all parties.

In the new ballot design, the requirement to choose both a party and a candidate was abandoned and the choice was replaced with a simplified method in which voters need only select their candidate. The party preference is a byproduct of this choice, as each selection is made within the

\footnotetext{
${ }^{6}$ The situation was even worse for national elections, in which voters had to, in addition to marking the party and candidate's number, choose between a national district and a special national constituency for indigenous communities, and for the House, the department level district, or a national reserved seat for the indigenous communities or two reserved seats from Afro-Colombian descendants.
} 
area designated for a party. The redesign of the ballot should therefore have enabled voters to better translate their preferences into a selection of a candidate or a party.

Although this design simplifies choices in general, the ballot design should primarily affect populations with the most sensitivity to usability issues. The greater the effort and information burden required to use the ballot, the more difficulty we would expect for those most susceptible to these usability problems, such as less educated or politically sophisticated citizens, resulting in a greater tendency to make mistakes using the ballot. The subsequent design, by simplifying its use, should have reduced the disparities between these groups and made demographic characteristics less important in explaining the propensity of voters to produce invalid votes.

\section{An Experiment in Bogotá}

To test the differences across the ballots and isolate the role of the ballot in producing the effects, we conducted an experiment based on the Bogotá Council elections that varied ballot design and the instructions given to voters and assessed aspects of voters such as age, sex, level of electoral participation, socioeconomic status, and education level. One ballot design was based on that used in 2007 (that shown in Figure 3), while the second was based on a proposed alternative to be used in 2011 (that shown in Figure 4a). The study was conducted with the support of the National Registry on March 17, 18, and 22, 2011.

The voting simulations were conducted in the auxiliary registration offices of the Colombian capital. These offices are responsible for issuing all records and credentials relating to identity and elections. Because virtually all Colombians make use of these services, a sample producing variation by gender, age, and socioeconomic status of the larger electorate was obtained. Student volunteers gave visitors the survey, randomly assigning individuals to receive a version of the Bogotá council ballot (2007 or 2011) and a set of instructions. Overall, 1,257 individuals participated in the simulations described below. See Annex 1 for descriptive statistics on the sample. Volunteers were instructed to ask everyone that entered the registration offices to participate.

The randomly-assigned instructions were to simulate the actual voting intention and allow variation across which type of intent corresponds to which type of error (See Annex 1 to see the sample described by type of instruction). The first group of instructions we examine, Candidate Number, gave the subject the candidate number as well as either the party logo or the names of parties. A second set of instructions, Name Only, used the name of the party and the name of a particular candidate without the number. The Candidate Number instructions more closely simulate the typical level of information where voters are aware of the candidates' numbers, while the Name Only instructions deals with the possibility of voters without this information being forced to find it on the spot using only materials provided on site. In this case, the subject needed to search the number of the candidate in a booklet similar to that provided by the National Registry in the election booth. 


\section{Results of Simulation}

To show the results regarding the ballot types and test the conditioning effects of the self-reported socio-demographic characteristics on the effective use of the ballot, we use a probit model in which the dependent variable was a dummy variable identifying whether the subject cast an invalid ballot. As independent variables, we created dummies for the instruction categories just described. In the first model, we simply examine the effect of the ballot. In the second and third models we interact ballot with the level of education reported by the subject, divided into higher education and lower categories. In the third model we add a series of interactions with the type of instruction, which were grouped into the categories Candidate Number (which also included party information), and the Name Only instruction, in which voters had to consult additional materials to cast the ballot.

Table 2 about here

Table 2 shows that the new ballot does overall reduce the probability of spoiling the ballot. The new design clearly improves usability compared to the 2007 ballot. To better observe the difference, Figure 5 displays the predicted values (from Model 1) in the differences in probability of spoiling the ballot differentiating by ballot type, showing a decline from $16.7 \%$ in 2007 to $2.5 \%$ in the 2011 ballot.

Figure 5 about here

Figure 6 displays the predicted values from Model 2, examining the ballot effect between the two categories of education of which the lowest category represents those subjects with secondary education or less, and the upper category represents subjects with at least some college (technical/university) education.

Figure 6 about here

For the 2007 ballot, education is important in explaining the probability of spoiling the ballot. The 2011 ballot, by contrast, is used more effectively by all users. At low levels of education, the difference between the two ballot designs is stark - with a difference of $4.1 \%$ to $21.1 \%$ in the lowest category. While the gap narrows in the higher education group, there is a statistically significant difference between the ballot types within both groups.

While education level has an effect overall, we also want to observe how the instructions (the information given to the subject) influenced the outcome. Figure 7 displays the results of Model 3 , differentiated by type of instruction.

Figure 7 about here

As described above, the first category of instructions gave the subject the number of the candidate, along with either the logo or the party name. The second set of instructions gave only 
the name of the candidate and name of the party, which required the use of a booklet to determine the candidate's number and party logo. When the data is divided to these types two type of instructions, we see the pattern associated with the effect of education on the larger sample, showing that with the 2007 ballot the chances of spoiling the ballot were significantly higher than for subjects assigned the 2011 ballot. With our second set of instructions, the subject had to search into other material to find out the number of the candidate. This was intended to simulate a lower level of information than voters typically possess, though it also has the effect of drawing additional attention to details of the process. The results are generally similar although the difference across education groups is somewhat more stark with the 2011 ballot and less differentiated with the 2007 ballot, compared to the other instructions.

\section{Observed Outcomes: 2007 and 2011 Municipal Council Results Compared}

The results from the experiment above formed the basis for the National Registry's decision to implement the new 2011 ballot for the October elections, which included minor changes to the design used in the study just described (shown in Figure $4 b){ }^{7}$

That same year, in October, the new ballot with the improved design made its first public appearance for the elections of local authorities. This enables us to examine whether the applications of both ballots reflects the expectations above.

In this context, however, we are limited to aggregate data, which forces us to rely on very indirect measures of general voter characteristics. We use the municipality as the unit of observation and the percentage of rejected ballots as the dependent variable. We make use of the urbanization rate as a proxy for social and political dynamics that could have an effect on the probability of spoiling a ballot, which may roughly correspond to the degree of familiarity with the party system and electoral process. As a result, we expect that rural areas are likely to have voters more vulnerable to ballot usability issues. This is the main focus of our investigation below.

We also include control variables that might have a potential effect on the context of voting, especially ones that could motivate protest or contribute to voter apathy. First, due to the particular circumstances of political conflict in Colombia, we included a rate of homicides per 100,000 inhabitants. Particularly if protest motivations drive ballot behavior, we might expect that violence would increase the potential for frustration with the political system and thus lead to more invalid votes. Second, we also include measures to capture the competitiveness of the mayoral race, which is held concurrently and more salient than the councilors race. These also might be related to contexts where protest activity might be expected due to elections in dominant political machines or otherwise lacking viable competitors, following the reasoning of work such

\footnotetext{
${ }^{7}$ It included a larger illustrated instruction section as well as letters to the left of party logos to facilitate counting the ballots.
} 
as Uggla (2008). For that purpose, we added the winning margin (as a percentage) between the winner and the first loser for the mayoral race. Our intuition was that when there exists more certainty over the election result - reflected in a higher margin between candidates -- citizens may not participate as actively in political choices as in politically competitive environments race with multiple strong candidates. Further, we include the effective number of candidates per seat at the municipal level for the council election, which partly accounts for the complexity of the context (Power and Garand 2007; Tomsa and Ofen 2013, p. 82). A more fragmented system could increase the number of potentially relevant and visible candidates voters would have to consider.

Finally, we also examine a model with the same covariates using "blank votes" - the explicit protest option Colombia includes on the ballot -- as an alternate dependent variable for comparison to invalid votes. In Colombia, as noted above, blank votes are officially allowed, counted and reported. For many citizens interested in protest activity, this is known to serve as an explicit demonstration of discontent (Caicedo, 2015, p.63). ${ }^{8}$ This allows us to compare the effect the ballot (and other variables) on this more clear-cut pattern of protest activity, relative to the effect on invalid votes. If invalid votes are also related to protest activity, we would expect somewhat similar results for key variables when comparing the same models applied to blank votes.

The three models are reported in Table 3. We use department fixed effects to account for the possibility that there could be regional characteristics of local politics that could influence the baseline tendencies in each department, and cluster on municipality. The first column shows the model of rejected ballots including the variables above. To observe the differences in our variable of interest before and after the reform, the variables are interacted with a dummy for the 2011 ballot in the second model (Column 2). The third column shows the same model with blank votes as the dependent variable.

\section{Table 3 about here}

Our first result confirms again that the 2011 ballot lead to fewer invalid votes, on average, with a 2.75 percentage point decrease of invalid votes between 2007 and 2011 -about $38 \%$ fewer.

Second, the urban percent of the population clearly decreases the number of invalid votes overall. In the next model, the interactions show a stark difference with regard to the effect of this demographic factor. The negative relationship -- more urban municipalities having fewer invalid votes - is seen in 2007 but this difference disappears in 2011 after the ballot redesign. A plot of the predicted values of this relationship showing the difference between the 2007 and 2011

\footnotetext{
${ }^{8}$ As illustrated by Caicedo (2015), in some mayoral races, blank votes have surpassed the votes of candidates. Due to existing legislation, those races need have to be rescheduled with a new set of candidates (Caicedo 2015).
} 
ballots are depicted in Figure 8 (Table 3, Model 2).

Figure 8 about here

The linear prediction shows that for the 2007 election the proportion of invalid votes was higher in the more rural municipalities, at around $8.05 \%$ compared to $6.0 \%$ for the urban municipalities. The introduction of the new ballot in 2011 made a significant change in the overall proportion of invalid votes, lowering its average to $4.43 \%$. Further, with the 2011 ballot there is no statistically significant effect of the degree of urbanness, suggesting the demographic factors captured by this variable were no longer present.

The effective number of candidates per seat meanwhile slightly decreases the number of null votes. This is contrary to expectations, though the interaction model shows that this effect was also not present in 2011. Less competitive mayoral elections had no statistically significant effect on the number of invalid votes overall. A weak negative effect for this variable in 2007 was not present in 2011. In addition, there is positive association between violence (homicide rate) and invalid votes, however the interaction model suggests that the effect does not vary between the two elections.

Finally, we conduct an additional analysis in which use the same model with the percentage of blank votes as the dependent variable as, reported in Column 3. As noted above, these blank votes serve as a straightforward opportunity to cast a protest vote for voters not intending to make a choice. First we note that there is no statistically significant difference between 2007 and 2011. While the 2011 ballot was negatively correlated and significant for invalid votes, this relationship does not hold for blank votes. Second, as shown in Figure 9, and the effect of urban population has the opposite effect for blank votes, compared to invalid votes. Although there is a small statistically significant difference between the years in the magnitude of this effect, the figure illustrates that there is substantial difference compared to 2007.

Figure 9 about here

In summary, while invalid votes diminish with urban proportion only with the 2007 ballot (as we would expect given the usability hypothesis), blank vote proportions increase with urbanness at roughly the same rate in both years. This is what we would expect given that active protest balloting should be associated with the higher political sophistication or awareness one would expect in urban areas. In addition, this is consistent with Caicedo's (2015) finding that voters in "cosmopolitan" areas tend to mobilize protests using this method.

\section{Concluding Points}

Our results suggest that how an electoral system functions is partly a result of the ballot design. Here, we focus on tendency for complex ballot tasks to undermine the ability of votes to cast valid ballots. Our findings suggest that the introduction of a combined party and candidate component to the ballot in an environment where pure candidate votes were the norm 
exacerbated the detrimental effects that the open list reform had on voter's ability to make their vote count. The 2011 ballot design, which nested candidate choice within party dramatically reduced the tendency for subjects in simulated conditions to produce invalid votes simply by making the process more consistent with the information required under the candidate-only ballot previously used. We also find that lower education and higher age groups were likely disproportionately affected by the usability weakness of the 2007 ballot. Examining the actual results in this light, we see some evidence that the basic effect of reducing these disparities has likely occurred in practice. In addition to the fact that the average proportion of invalid votes reduced markedly from 2007 to 2011, a measurable disparity between more rural and urban municipalities found 2007 was no longer present in 2011. Moreover, there is no clear evidence that protest voting motivated these votes in either election, though there is some evidence that casting blank votes may have served this role in both elections.

Invalid votes driven by usability factors mean that voters are effectively excluded from political participation. Normatively, maximizing usability means that all voters count without undue burdens and without bias against certain populations, such as the less educated. Removing such bias increases the legitimacy of elections and improves equality of influence in democracy. Overall, extrapolating from the 2007 council data, as many as 260,000 additional votes would have been wasted if the same proportion of invalid votes had occurred in 2011. Although we do not investigate the political consequences here, we do establish that the effects were likely concentrated on the less educated citizens and perhaps other less politically sophisticated groups. This implies that, at a minimum, the removal of these votes from the process lead to systematic underrepresentation of certain views in society and could therefore bias political outcomes. 


\section{References}

Agresti, A., Presnell, B., 2002. Misvotes, undervotes and overvotes: The 2000 presidential election in Florida. Statistical Science 17(4), 436-440.

Aldashev, G., Mastrobuoni, G., 2010. Invalid Ballots and Electoral Competition. Carlo Alberto Notebooks 153,1-39.

Alvarez, R. M., Sinclair, D.E., 2004. Who overvotes, who undervotes, using punchcards? Evidence from Los Angeles County. Political Research Quarterly 57(1), 15-25.

Álvarez, R. M., Goodrich, M., Hall, T. E., Kiewiet, D. R., Sled, S. M. 2004. The complexity of the California recall election. Political Science and Politics 37(1), 23-26.

Alvarez, R. M., Hartman, E., Hill, S., Katz, J. N., 2009. Machines Versus Humans: The Counting and Recounting of Pre-Scored Punchcard Ballots. In CELS 2009 4th Annual Conference on Empirical Legal Studies Paper.

Alvarez, R. M., Katz, G., Llamosa R., Martinez, H. E., 2009. Assessing Voters' Attitudes towards Electronic Voting in Latin America: Evidence from Colombia's 2007 E-Voting Pilot. Springer Berlin Heidelberg.

Alvarez, R. M., Sinclair, D. E., Wilson, C. H. 2004. Counting ballots and the 2000 election: What went Wrong? Oxford University Press.

Alvarez, R.M., Kiewiet, D.R., Núñez, L., 2016. “A Taxonomy of Protest Voting.” Paper prepared for delivery at the Annual Meeting of the Conference on Elections, Public Opinion, and Parties, University of Kent, September 9-11, 2016.

Ansolabehere, S., Stewart, C.S., 2005. Residual votes attributable to technology. Journal of Politics 67(2), 365-389.

Ansolabehere, S., 2002. Voting machines, race, and equal protection. Election Law Journal 1(1), 61-70.

Ansolabehere, S., 2002. Voting machines, race, and equal protection. Election Law Journal 1(1), 61-70.

Arbache, G., Freire, D., Rodrigues, P., 2015. Invalid Votes, Political Efficacy and Lack of Preferences in Brazilian Elections. Manuscript.

Bonneau, C. W., Loepp, E., 2014. Getting things straight: The effects of ballot design and electoral structure on voter participation. Electoral Studies 34, 119-130.

Buchler, J., Jarvis, M., McNulty, J. E., 2004. Punch card technology and the racial gap in residual votes. Perspectives on Politics 2(3), 517-524. 
Bullock III, C. S., Hood III, M. V., 2002. One person-no vote; one vote; two votes: voting methods, ballot types, and undervote frequency in the 2000 presidential election. Social Science Quarterly, 981-993.

Caicedo, J., 2015. Abstención electoral y voto en blano en la consolidación demorática colombiana. En F. Barrero y M. Batlle, Elecciones en Colombia, 2014 ¿Representaciones fragmentadas? (pp. 45-85). Bogotá: Fundación Konrad Adenauer

Caltech/MIT Voting Project., 2001. "Residual Votes Attributable to Technology: An Assessment of the Reliability of Existing Voting Equipment.” Unpublished manuscript available at www.vote.caltech.edu.

Calvo, E., Escolar, M., Pomares, J.S., 2009. Ballot Design and Split Ticket Voting in Multiparty Systems: experimental evidence on information effects and vote choice. Electoral Studies 28(2), 218-231.

Carey, J. M., Shugart, M. S., 1995. Incentives to Cultivate a Personal Vote: a Rank Ordering of Electoral Formulas. Electoral Studies 14(4), 417-439.

Carman, C., Mitchell, J., Johns, R., 2008. The unfortunate natural experiment in ballot design: the Scottish Parliamentary Elections of 2007. Electoral Studies 27(3), 442-459.

Hanmer, M. J., Park, W.H., Traugott, M. W., Niemi, R. G., Herrnson, P. S., Bederson, B. B., Conrad, F. C., 2010. Losing Fewer Votes The Impact of Changing Voting Systems on Residual Votes. Political Research Quarterly 63(1), 129-142.

Herrnson, P. S., Niemi, R. G., Hanmer, M. J., Francia, P. L., Bederson, B. B., Conrad, F. G., Traugott, M. W., 2008. Voters' Evaluations of Electronic Voting Systems Results From a Usability Field Study. American Politics Research 36(4), 580-611.

Herrnson, P. S, Hanmer, M. J., Niemi, R. G., 2012. The Impact of Ballot Type on Voter Errors. American Journal of Political Science 56(3), 716-730.

Herrnson, P.S., Niemi, R.G., Hanmer, M.J., Bederson, B.B., Conrad, F.C., 2008. Voting Technology: The Not-So-Simple Act of Casting a Ballot. Brookings Institution Press, Washington.

Herron, M. C., Sekhon, J. S., 2003. Overvoting and Representation: An examination of overvoted presidential ballots in Broward and Miami-Dade counties. Electoral Studies 22(1), 2147.

Hill, L., Young, S., 2007. Protest or error? Informal voting and compulsory voting. Australian Journal of Political Science 42(3), 515-521. 
Katz, G., Alvarez, R. M., Calvo, E., Escolar, M., Pomares, J., 2011. Assessing the Impact of Alternative Voting Technologies on Multi-Party Elections: Design Features, Heuristic Processing and Voter Choice. Political Behavior 33(2), 247-270.

Kimball, D., Kropf M., 2005. Ballot Design and Unrecorded Votes on Paper-Based Ballots. Public Opinion Quarterly 69(4), 508-529.

Kimball, D. C., Owens, C. T., Keeney, K. M., Watson, R. P., 2004. Unrecorded votes and political representation. Counting Votes: Lessons from the 2000 Presidential Election in Florida. University Press of Florida, 135-50.

Knack, S., Kropf, M., 2003. Roll-Off at the Top of the Ballot: International Undervoting in American Presidential Elections. Politics \& Policy 31(4), 575-594.

Leib, J. I., Dittmer, J., 2002. Florida's residual votes, voting technology, and the 2000 election. Political Geography 21(1), 91-98.

Matson, M., Fine, T. S., 2006. Gender, Ethnicity, and Ballot Information: Ballot Cues in LowInformation Elections. State Politics \& Policy Quarterly 6(1), 49-72.

McAllister, I., Makkai, T., 1993. Institutions, society or protest? Explaining invalid votes in Australian elections. Electoral Studies 12(1), 23-40.

Mebane, W. R., 2004. The wrong man is president! Overvotes in the 2000 presidential election in Florida. Perspectives on Politics 2(3), 525-535.

Moral, M., 2016. The Passive-Aggressive Voter The Calculus of Casting an Invalid Vote in European Democracies. Political Research Quarterly, p.1065912916662356.

Neely, F., Cook, C., 2008. Whose votes count? Undervotes, overvotes, and ranking in San Francisco's instant-runoff elections. American Politics Research 36(4), 530-554.

Posner, R. A., 2001. Breaking the deadlock: The 2000 election, the constitution, and the courts. Princeton University Press.

Power, T. J., Garand, J. C., 2007. Determinants of invalid voting in Latin America. Electoral Studies 26(2), 432-444.

Power, T. J., Roberts, J., 1995. Compulsory Voting, Invalid Ballots, and Abstention in Brazil. Political Research Quarterly 48(4), 795-826.

Reynolds, A., Steenbergen M., 2006. How the world votes: The political consequences of ballot design, innovation and manipulation. Electoral Studies 25(3), 570-598.

Sinclair, D. E., Alvarez, M., 2004. Who Overvotes, Who Undervotes, Using Punchcards?

Evidence from Los Angeles County. Political Research Quarterly 57(1), 15-25. 
Steifbold, Rodney., 1965. "The Significance of Void Ballots in West German Elections." American Political Science Review 59(2), 391-407.

Superti, Chiara., 2016. "The Blank and Null Vote: An Alternative Form of Democratic Protest. Manuscript, Harvard University

Taylor, S. L., 2012. Colombian Voters and Ballot Structure: Error, Confusion, and/or "None of The Above". The Latin Americanist 56(4), 111-130.

Tomsa, D., Ufen, A., 2013. Party Politics in Southeast Asia: Clientelism and Electoral Competition in Indonesia, Thailand and the Philippines. New York: Routledge.

Tomz, M.,Van Houweling, R. P., 2003. How Does Voting Equipment Affect the Racial Gap in Voided Ballots? American Journal of Political Science 47(1), 46-60.

Traugott, M. W., Hanmer, M. J., Park, W., Herrnson, P. S., Niemi, R. G., Bederson, B. B., Conrad, F. G., 2005. The impact of voting systems on residual votes, incomplete ballots, and other measures of voting behavior. In annual conference of the Midwest Political Science Association, Chicago, IL, April

Uggla, F., 2008. Incompetence, alienation, or calculation ? : Explaining levelds of invalid ballots and extra-parliamentary votes. Comparative Political Studies 41 (8), 1141-1164.

Zulfikarpasic, A., 2001. Le vote blanc: abstention civique ou expression politique?. Revue française de science politique 51(1), 247-268. 
Table 1. Rejected Ballots Divided by Type of Use Rejected ballots divided by type of use

Rejected ballots

Frequency $\%$

1. Voter does not choose a party, and only chooses a candidate number

2. Voter marks more than one party logos, no number of candidate

3. Voter marks all areas

4. Other types of marks that spoil the ballot

Total Source: Authors, sample tak
across localities in Bogotá.

\begin{tabular}{cc}
969 & $71.2 \%$ \\
256 & $18.8 \%$ \\
64 & $4.7 \%$ \\
73 & $5.4 \%$ \\
\hline 1362 & $100 \%$ \\
\hline
\end{tabular}


Table 2. Simulation Results, Probit Estimates

\begin{tabular}{|c|c|c|c|}
\hline $\begin{array}{l}\text { Model } \\
\text { Variables } \\
\end{array}$ & $\begin{array}{c}(1) \\
\text { Invalid vote }\end{array}$ & $\begin{array}{c}(2) \\
\text { Edu. Interactions } \\
\end{array}$ & $\begin{array}{c}\text { (3) } \\
\text { Edu./Instruc/Interac } \\
\end{array}$ \\
\hline 2011 Ballot & $\begin{array}{l}-0.981 * * * \\
(0.120)\end{array}$ & $\begin{array}{l}-0.934 * * * \\
(0.150)\end{array}$ & $\begin{array}{l}-1.002 * * * \\
(0.213)\end{array}$ \\
\hline Higher Education & & $\begin{array}{c}-0.345^{* * *} \\
(0.124)\end{array}$ & $\begin{array}{c}-0.423 * * \\
(0.167)\end{array}$ \\
\hline 2011 Ballot*Higher Education & & $\begin{array}{l}-0.173 \\
(0.260)\end{array}$ & $\begin{array}{l}0.0167 \\
(0.337)\end{array}$ \\
\hline Instruction Name only & & & $\begin{array}{c}-0.122 \\
(0.164)\end{array}$ \\
\hline $2011 *$ Name only & & & $\begin{array}{c}0.153 \\
(0.302)\end{array}$ \\
\hline Higher Ed*Name only & & & $\begin{array}{c}0.180 \\
(0.251)\end{array}$ \\
\hline $2011 *$ Higher.Ed*Name only & & & $\begin{array}{l}-0.493 \\
(0.555)\end{array}$ \\
\hline Constant & $\begin{array}{c}-0.965 * * * \\
(0.0609)\end{array}$ & $\begin{array}{c}-0.809 * * * \\
(0.0809)\end{array}$ & $\begin{array}{c}-0.758 * * * \\
(0.106)\end{array}$ \\
\hline Observations & 1,257 & 1,253 & 1,253 \\
\hline
\end{tabular}

Standard errors in parentheses

$* * * \mathrm{p}<0.01, * * \mathrm{p}<0.05, * \mathrm{p}<0.1$ 
Table 3. Model to test the Effect of the Ballot on Invalid votes, Council Results 2007-2011

\begin{tabular}{|c|c|c|c|}
\hline $\begin{array}{l}\text { Model } \\
\text { Variables }\end{array}$ & $\begin{array}{c}\text { (1) } \\
\text { Invalid votes }\end{array}$ & \begin{tabular}{l}
\multicolumn{1}{c}{$(2)$} \\
Invalid Votes \\
Interactions
\end{tabular} & $\begin{array}{c}(3) \\
\text { Blank votes }\end{array}$ \\
\hline 2011 Ballot & $\begin{array}{c}-2.757 * * * \\
(0.0625)\end{array}$ & $\begin{array}{c}-4.846^{* * *} \\
(0.301)\end{array}$ & $\begin{array}{l}-0.0644 \\
(0.210)\end{array}$ \\
\hline Urban Proportion & $\begin{array}{l}-0.578^{* * *} \\
(0.205)\end{array}$ & $\begin{array}{c}-1.336 * * * \\
(0.239)\end{array}$ & $\begin{array}{c}3.566 * * * \\
(0.166)\end{array}$ \\
\hline 2011 Ballot*Urban proportion & & $\begin{array}{c}1.582 * * * \\
(0.232)\end{array}$ & $\begin{array}{c}0.661 * * * \\
(0.222)\end{array}$ \\
\hline ENEC per seat & $\begin{array}{c}-0.156^{* *} \\
(0.0625)\end{array}$ & $\begin{array}{c}-0.383^{* * * *} \\
(0.0914)\end{array}$ & $\begin{array}{c}-0.183 * * * \\
(0.0471)\end{array}$ \\
\hline 2011 Ballot*ENEC per seat & & $\begin{array}{c}0.393^{* * *} \\
(0.0846)\end{array}$ & $\begin{array}{l}-0.0315 \\
(0.0605)\end{array}$ \\
\hline Winning margin & $\begin{array}{l}-0.178 \\
(0.300)\end{array}$ & $\begin{array}{c}-0.717 * \\
(0.425)\end{array}$ & $\begin{array}{c}0.139 \\
(0.257)\end{array}$ \\
\hline 2011 Ballot*Winning margin & & $\begin{array}{l}1.008^{*} \\
(0.593)\end{array}$ & $\begin{array}{l}-0.231 \\
(0.404)\end{array}$ \\
\hline Homicide rate & $\begin{array}{l}3.727 * * * \\
(1.265)\end{array}$ & $\begin{array}{c}2.875^{* * *} \\
(1.424)\end{array}$ & $\begin{array}{l}-0.875 \\
(0.755)\end{array}$ \\
\hline 2011 Ballot*Homicide rate & & $\begin{array}{c}1.616 \\
(1.246)\end{array}$ & $\begin{array}{l}-0.315 \\
(0.971)\end{array}$ \\
\hline Department Effects & YES & YES & YES \\
\hline Constant & $\begin{array}{c}9.085^{* * *} * \\
(0.246)\end{array}$ & $\begin{array}{c}10.16^{* * * *} \\
(0.317)\end{array}$ & $\begin{array}{c}1.127 * * * \\
(0.163)\end{array}$ \\
\hline Observations & 1,947 & 1,946 & 1,946 \\
\hline $\mathrm{R}$-squared & 0.517 & 0.533 & 0.500 \\
\hline
\end{tabular}

Robust standard errors in parentheses $* * * \mathrm{p}<0.01, * * \mathrm{p}<0.05, * \mathrm{p}<0.1$ 


\section{Appendix}

Table A1: Sample of Participants Divided by Locality and Type of Ballot

\begin{tabular}{lll} 
Locality & \multicolumn{2}{c}{ Ballot } \\
\hline Suba & 2007 & 2011 \\
Usaquén & 74 & 71 \\
San Cristóbal & 16 & 92 \\
Teusaquillo & 80 & 25 \\
Candelaria & 226 & 231 \\
Tunjuelito & 21 & 35 \\
Kennedy & 19 & 31 \\
Chapinero & 64 & 81 \\
Fontibón & 97 & 101 \\
Puente Aranda & 32 & 30 \\
Oficinas & & \\
Centrales & 92 & 97 \\
\hline Total & 820 & 876 \\
\hline
\end{tabular}

Table A2. Simulated Ballot by Type of Instruction and Type of Ballot

\begin{tabular}{lccccc}
\hline Type of Instruction & 2007 & $\%$ & 2011 & $\%$ & Total \\
\hline Number of Candidate & 334 & 55.85 & 351 & 53.26 & 685 \\
& & & & & \\
Name of Candidate & 264 & 44.15 & 308 & 46.74 & 572 \\
\hline Total & 598 & & 659 & & 1257
\end{tabular}

*Additional participants that were involved in two other activities designed to simulate closed list and blank voting were not included in the analysis.

Experiment Sample: Socio-demographic Characteristics

Table A3. Sample Differentiated by Sex

\begin{tabular}{lrrrrrr}
\hline & 2007 & $\%$ & 2011 & $\%$ & Total & $\%$ \\
\hline Male & 252 & 42.1 & 308 & 46.7 & 560 & 44.6 \\
Female & 346 & 57.9 & 351 & 53.3 & 697 & 55.4 \\
\hline Total & 598 & & 659 & & 1257 & \\
\hline
\end{tabular}


Table A4. Sample Differentiated by Self-Reported Economic Strata

\begin{tabular}{|c|c|c|c|c|c|c|c|}
\hline & & 2007 & $\%$ & 2011 & $\%$ & Total & $\%$ \\
\hline \multirow{5}{*}{$\begin{array}{l}1 \text { (Lowest } \\
\text { income) }\end{array}$} & & 30 & 5.2 & 48 & 7.4 & 78 & 6.3 \\
\hline & 2 & 156 & 26.8 & 193 & 29.7 & 349 & 28.3 \\
\hline & 3 & 244 & 41.9 & 250 & 38.5 & 494 & 40.1 \\
\hline & 4 & 125 & 21.4 & 107 & 16.5 & 232 & 18.8 \\
\hline & 5 & 16 & 2.7 & 36 & 5.5 & 52 & 4.2 \\
\hline $\begin{array}{l}6 \text { (Highest } \\
\text { income) }\end{array}$ & & 12 & 2.1 & 15 & 2.3 & 27 & 2.2 \\
\hline Total & & 583 & & 649 & & 1232 & \\
\hline
\end{tabular}

Table A5. Sample Differentiated by Age Group

\begin{tabular}{lrrrrrr}
\hline & 2007 & $\%$ & 2011 & $\%$ & Total & $\%$ \\
\hline $18-25$ & 193 & 32.3 & 227 & 34.5 & 420 & 33.4 \\
$26-35$ & 147 & 24.6 & 135 & 20.5 & 282 & 22.4 \\
$36-45$ & 110 & 18.4 & 124 & 18.8 & 234 & 18.6 \\
$46-55$ & 85 & 14.2 & 108 & 16.4 & 193 & 15.3 \\
56 or more & 63 & 10.5 & 65 & 9.9 & 128 & 10.2 \\
\hline Total & 598 & & 659 & & 1257 & \\
\hline
\end{tabular}

Table A6. Sample Differentiated by Educational Attainment

\begin{tabular}{lrrrrrr}
\hline & 2007 & $\%$ & 2011 & $\%$ & Total & $\%$ \\
\hline First category & & & & & & \\
$\quad$ Primary & 43 & 7.2 & 44 & 6.7 & 87 & 6.9 \\
$\quad$ High School & 263 & 44.1 & 276 & 42.0 & 539 & 43.0 \\
Second category & & & & & & \\
Technical & 111 & 18.6 & 122 & 18.6 & 233 & 18.6 \\
University & 130 & 21.8 & 162 & 24.7 & 292 & 23.3 \\
Grad. Studies & 49 & 8.2 & 53 & 8.1 & 102 & 8.1 \\
\hline Total & 596 & & 657 & & 1253 & \\
\hline
\end{tabular}

Table A7. Sample Differentiated by Total Valid and Invalid Votes, Simulation by Type of Ballot

\begin{tabular}{lrrrrr} 
& 2007 & $\%$ & 2011 & $\%$ & Total \\
\hline $\begin{array}{l}\text { Valid votes } \\
\text { Invalid }\end{array}$ & 498 & $83.3 \%$ & 642 & $97.4 \%$ & 1140 \\
votes & 100 & $16.7 \%$ & 17 & $2.6 \%$ & 117 \\
\hline Total & 598 & & 659 & & 1257
\end{tabular}

Source: Elaborated by the authors 
CONCEJO DE MEDELLIN(ANTIOQUIA) -01001CO-

\begin{tabular}{|c|l|c|l|}
\hline \multicolumn{3}{|c|}{ MOVIMIENTO COLOMBIA VIVA } \\
\multicolumn{3}{|c|}{ LISTA CON VOTO PREFERENTE } \\
\hline 1
\end{tabular}

\begin{tabular}{|c|c|c|c|}
\hline \multicolumn{4}{|c|}{ MOVIMIENTO EQUIPO COLOMBIA } \\
\hline \multirow{2}{*}{\multicolumn{3}{|c|}{ 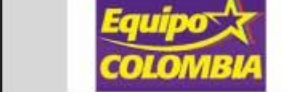 }} & 3 \\
\hline & & & VOTO \\
\hline \multicolumn{4}{|c|}{ LISTA CON VOTO PREFERENTE } \\
\hline 1 & $\begin{array}{l}\text { JENARO } \\
\text { PEREZ G }\end{array}$ & 10 & $\begin{array}{l}\text { ANA ISABEL } \\
\text { USUGA }\end{array}$ \\
\hline 2 & $\begin{array}{l}\text { LILIANA } \\
\text { RENDON ROLDAN }\end{array}$ & 11 & $\begin{array}{l}\text { DIEGO } \\
\text { TORO }\end{array}$ \\
\hline 3 & $\begin{array}{l}\text { JOHN JAIME } \\
\text { MONCADA }\end{array}$ & 12 & $\begin{array}{l}\text { LUIS FELIPE } \\
\text { JIMENEZ }\end{array}$ \\
\hline 4 & $\begin{array}{l}\text { CARLOS } \\
\text { CHAPARRO }\end{array}$ & 13 & $\begin{array}{l}\text { JORGE IVAN } \\
\text { NARANJO }\end{array}$ \\
\hline 5 & $\begin{array}{l}\text { GABRIEL JAIME } \\
\text { URREGO }\end{array}$ & 14 & $\begin{array}{l}\text { MARIA MERCEDES } \\
\text { LOPEZ }\end{array}$ \\
\hline 6 & $\begin{array}{l}\text { ALBEIRO } \\
\text { VALENCIA }\end{array}$ & 15 & $\begin{array}{l}\text { GUILLERMO } \\
\text { TORRES }\end{array}$ \\
\hline 7 & $\begin{array}{l}\text { MARCOS } \\
\text { CAICEDO }\end{array}$ & 16 & $\begin{array}{l}\text { LEONARDO } \\
\text { CORREA FERRUCHO }\end{array}$ \\
\hline 8 & $\begin{array}{l}\text { NELSON } \\
\text { RENDON }\end{array}$ & 17 & $\begin{array}{l}\text { BEATRIZ EUGENIA } \\
\text { LOPEZ }\end{array}$ \\
\hline 9 & $\begin{array}{l}\text { MARTIN EMILIO } \\
\text { RODRIGUEZ }\end{array}$ & & \\
\hline \multicolumn{4}{|c|}{ PARTIDO DEL TRABAJO DE COLOMBIA } \\
\hline & & & VOTO \\
\hline \multicolumn{4}{|c|}{ LISTA SIN VOTO PREFERENTE } \\
\hline & $\begin{array}{l}\text { JBEN DARIO } \\
\text { AIZA PEREZ }\end{array}$ & \multicolumn{2}{|c|}{$\begin{array}{l}\text { JAIME DE JESUS } \\
\text { GONZALEZ FLOREZ }\end{array}$} \\
\hline & $\begin{array}{l}\text { Y BEATRIZ } \\
\text { RAMILLO R }\end{array}$ & \multicolumn{2}{|c|}{$\begin{array}{l}\text { HORACIO DE JESUS } \\
\text { GUISAO ARIAS }\end{array}$} \\
\hline & $\begin{array}{l}\text { CARDO } \\
\text { RRES CHACON }\end{array}$ & \multicolumn{2}{|c|}{$\begin{array}{l}\text { DAISY ALEXANDRA } \\
\text { SANCHEZ VALDERRAMA }\end{array}$} \\
\hline & $\begin{array}{l}\text { BRIELA ANDREA } \\
\text { LLE MUNOZ }\end{array}$ & \multicolumn{2}{|c|}{$\begin{array}{l}\text { HEZVEN MARTIN } \\
\text { VELEZ VERGARA }\end{array}$} \\
\hline & $\begin{array}{l}\text { CIA AMPARO } \\
\text { PEZ DE C }\end{array}$ & \multicolumn{2}{|c|}{$\begin{array}{l}\text { BENANCIO DE J } \\
\text { ARIAS LOPEZ }\end{array}$} \\
\hline
\end{tabular}

\begin{tabular}{|l|l|l|l|}
\hline \multicolumn{3}{|c|}{ MOVIMIENTO NACIONAL } \\
\hline $\mathbf{1}$ & $\begin{array}{l}\text { ETSOMINA } \\
\text { MOSQUERA C }\end{array}$ & $\mathbf{5}$ & $\begin{array}{l}\text { OSCAR DARIO } \\
\text { CADAVID A }\end{array}$ \\
\hline $\mathbf{2}$ & $\begin{array}{l}\text { JORGE ELIECER } \\
\text { HENAO MUNOZ }\end{array}$ & $\mathbf{6}$ & $\begin{array}{l}\text { ORLANDA } \\
\text { MIRA ECHAVARRIA }\end{array}$ \\
\hline 3 & $\begin{array}{l}\text { JORGE MARIO } \\
\text { MONTOYA }\end{array}$ & $\mathbf{7}$ & $\begin{array}{l}\text { CARLOS ALBERTO } \\
\text { OSPINA MACIAS }\end{array}$ \\
\hline $\mathbf{4}$ & $\begin{array}{l}\text { FRANCISCO JOSE } \\
\text { AMAYA HERNANDEZ }\end{array}$ & $\mathbf{8}$ & $\begin{array}{l}\text { CARLOS ARTURO } \\
\text { CARDENAS LOPEZ }\end{array}$ \\
\hline
\end{tabular}

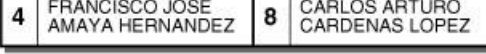

PARTIDO LIBERAL COLOMBIANO

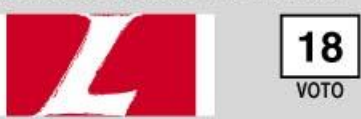

LISTA CON VOTO PREFERENTE

\begin{tabular}{|c|l|c|l|}
\hline 1 & $\begin{array}{l}\text { ALVARO } \\
\text { GOMEZJ }\end{array}$ & $\mathbf{1 1}$ & $\begin{array}{l}\text { PEDRO LEON } \\
\text { PORTELA M }\end{array}$ \\
\hline $\mathbf{2}$ & $\begin{array}{l}\text { MAXIMO } \\
\text { PEREZ SOTO }\end{array}$ & $\mathbf{1 2}$ & $\begin{array}{l}\text { ALVARO JOBANNY } \\
\text { GOMEZ }\end{array}$ \\
\hline $\mathbf{3}$ & $\begin{array}{l}\text { FABIO } \\
\text { ESTRADA CHICA }\end{array}$ & $\mathbf{1 3}$ & $\begin{array}{l}\text { CLAUDIA J } \\
\text { OSORNO OSORNO }\end{array}$ \\
\hline $\mathbf{4}$ & $\begin{array}{l}\text { SANTIAGO MANUEL } \\
\text { MARTINEZ M }\end{array}$ & $\mathbf{1 4}$ & $\begin{array}{l}\text { JOSE IVAN } \\
\text { MUNOZ ORREGO }\end{array}$ \\
\hline $\mathbf{5}$ & $\begin{array}{l}\text { GERMAN DARIO } \\
\text { HOYOS GIRALDO }\end{array}$ & $\mathbf{1 5}$ & $\begin{array}{l}\text { SERGIO } \\
\text { PEREZ ALVAREZ }\end{array}$ \\
\hline $\mathbf{6}$ & $\begin{array}{l}\text { FABIO HUMBERTO } \\
\text { RIVERA RIVERA }\end{array}$ & $\mathbf{1 6}$ & $\begin{array}{l}\text { TULIO MARIO } \\
\text { BOTERO URIBE }\end{array}$ \\
\hline 7 & $\begin{array}{l}\text { RAMON EMILIO } \\
\text { ACEVEDO C }\end{array}$ & $\mathbf{1 7}$ & $\begin{array}{l}\text { JOHN FREDY } \\
\text { TORO GONZALEZ }\end{array}$ \\
\hline $\mathbf{8}$ & $\begin{array}{l}\text { AURA MARLENY } \\
\text { ARCILA G }\end{array}$ & 18 & $\begin{array}{l}\text { GUILLERMO LEON } \\
\text { DIOSA PEREZ }\end{array}$ \\
\hline $\mathbf{9}$ & $\begin{array}{l}\text { NESTOR RAUL } \\
\text { MAYA MAYA }\end{array}$ & 19 & $\begin{array}{l}\text { JOSE JAIR } \\
\text { JIMENEZL }\end{array}$ \\
\hline 10 & $\begin{array}{l}\text { JOSE } \\
\text { LUJAN LOPEZ }\end{array}$ & $\mathbf{2 0}$ & $\begin{array}{l}\text { ANIBAL DE JESUS } \\
\text { MUNOZ A }\end{array}$ \\
\hline \hline
\end{tabular}

MOVIMIENTO UNITARIO METAPOLITICO
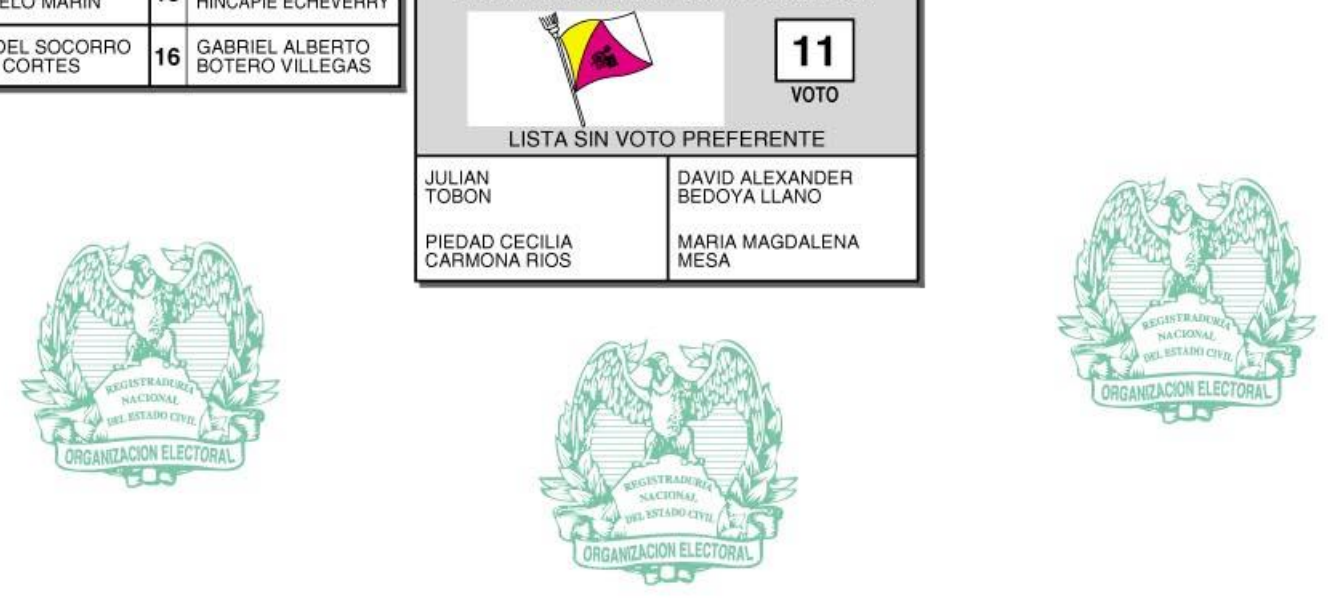

CONTINUA...

Figure 1: First Ballot Design Used after the 2003 Reform, Concejo de Medellín 
Text: A voter wishes to vote for candidate \#3 from Party 1 (Mario Aguirre Arias, from party Colombia Viva). The expected way to cast the vote would be to put a mark over the party name or number 1, and another mark over the number 3 or the candidate's name. Nonetheless, the voter could also mark only the name or candidate's number, or even just the party's name or number to cast a valid vote. 
Respetado Elector:

Para que su voto sea válido, diligencie una

sola PARTE A, B o C de esta tarjeta electoral

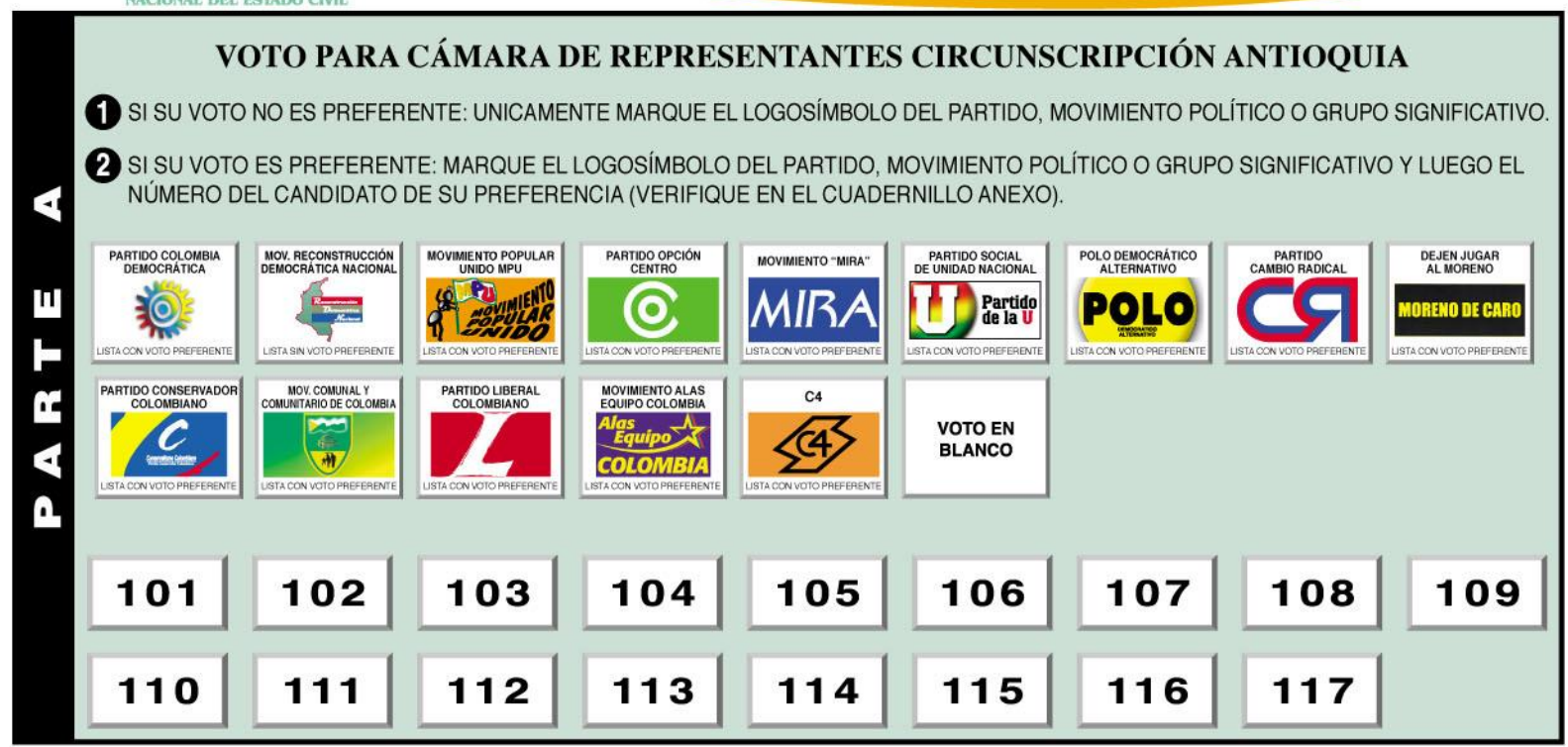

m VOTO PARA CÁMARA DE REPRESENTANTES CIRCUNSCRIPCIÓN ESPECIAL COMUNIDADES INDÍGENAS

mARQue el logosímbolo del PARTIDO, MOVIMIENTO Político o gRUPO SIGNIFICATIVO.
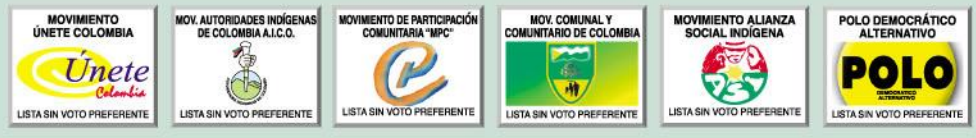

VOTO EN

VOTO PARA CÁMARA DE REPRESENTANTES CIRCUNSCRIPCIÓN ESPECIAL COMUNIDADES NEGRAS

(1) SI SU VOTO NO ES PREFERENTE: UNICAMENTE MARQUE EL LOGOSIMMBOLO DEL PARTIDO, MOVIMIENTO POLITICO O GRUPO SIGNIFICATIVO.

(2) SI SU VOTO ES PREFERENTE: MARQUE EL LOGOSIMBOLO DEL PARTIDO, MOVIMIENTO POLITICO O GRUPO SIGNIFICATIVO Y LUEGO EL NÚMERO DEL CANDIDATO DE SU PREFERENCIA (VERIFIQUE EN EL CUADERNILLO ANEXO).
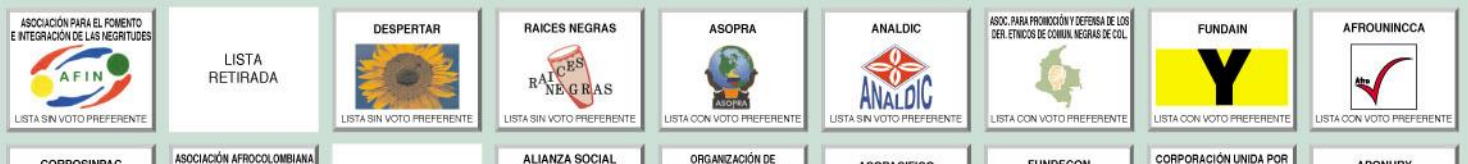

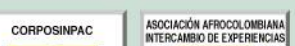
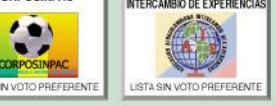

LISTA
RETIRADA
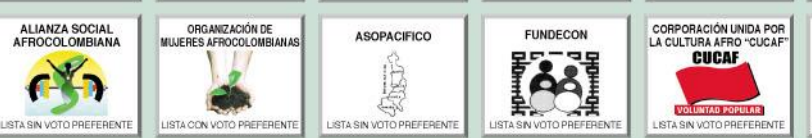

APONURY
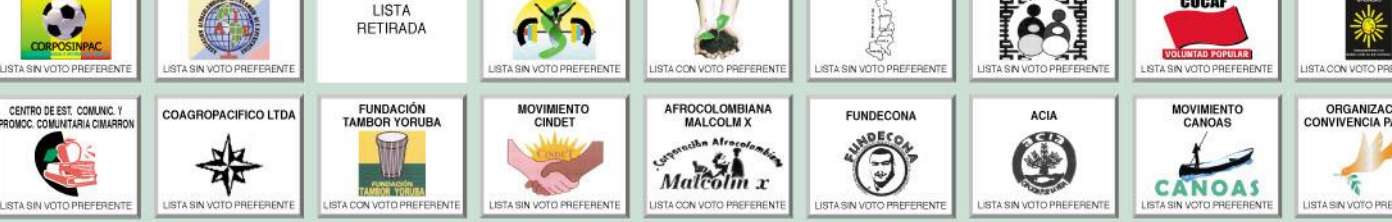

MOVIMIENTO NACION
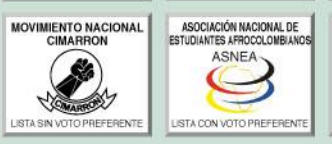

VOTO EN

301

302

Figure 2: Second Ballot Design (2006), National Elections. Ballot for the House of Representatives, Antioquia. 
Text Figure 2: In House elections, the voter must choose between part A, B or C. To cast a valid vote for candidate \#106 from the Liberal Party, for example, the voter should put a mark over the party logo, and another mark over the number \#106. The voter could also mark only the party logo. Invalid votes usually occur from only marking a number without marking the party logo, or marking multiple sections. In section B there are only party logos, because there is only one seat to allocate.

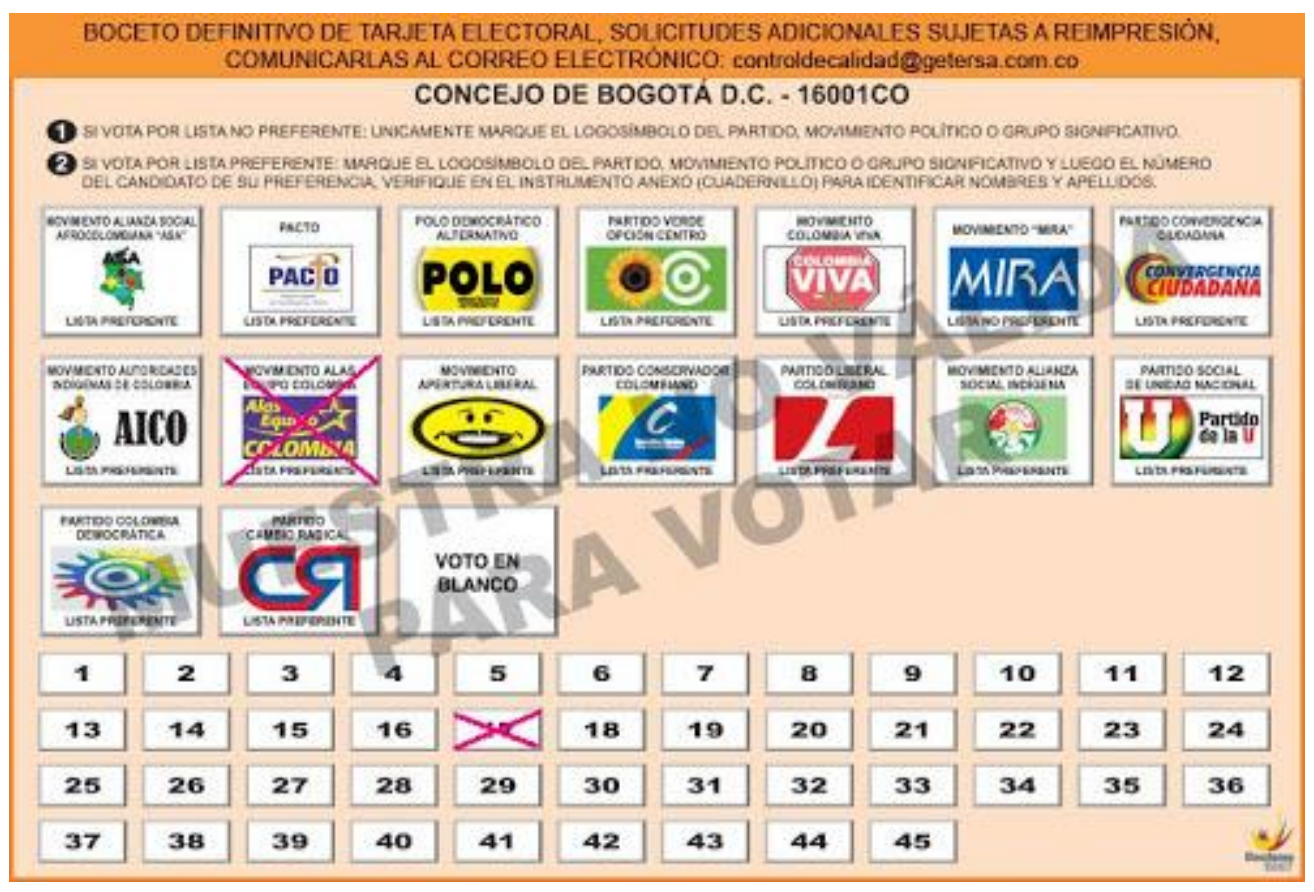

Figure 3: Second Ballot Design (2007), local elections. Concejo de Bogotá (Used for the simulation)

Text Figure 3: To cast a valid vote for candidate \#17 from the Movimiento Alas Equipo Colombia, the voter should put a mark over the party logo, and another mark over the number \#17. The voter could also mark only the party logo. Invalid votes usually occur from only marking a number without marking the party logo. 


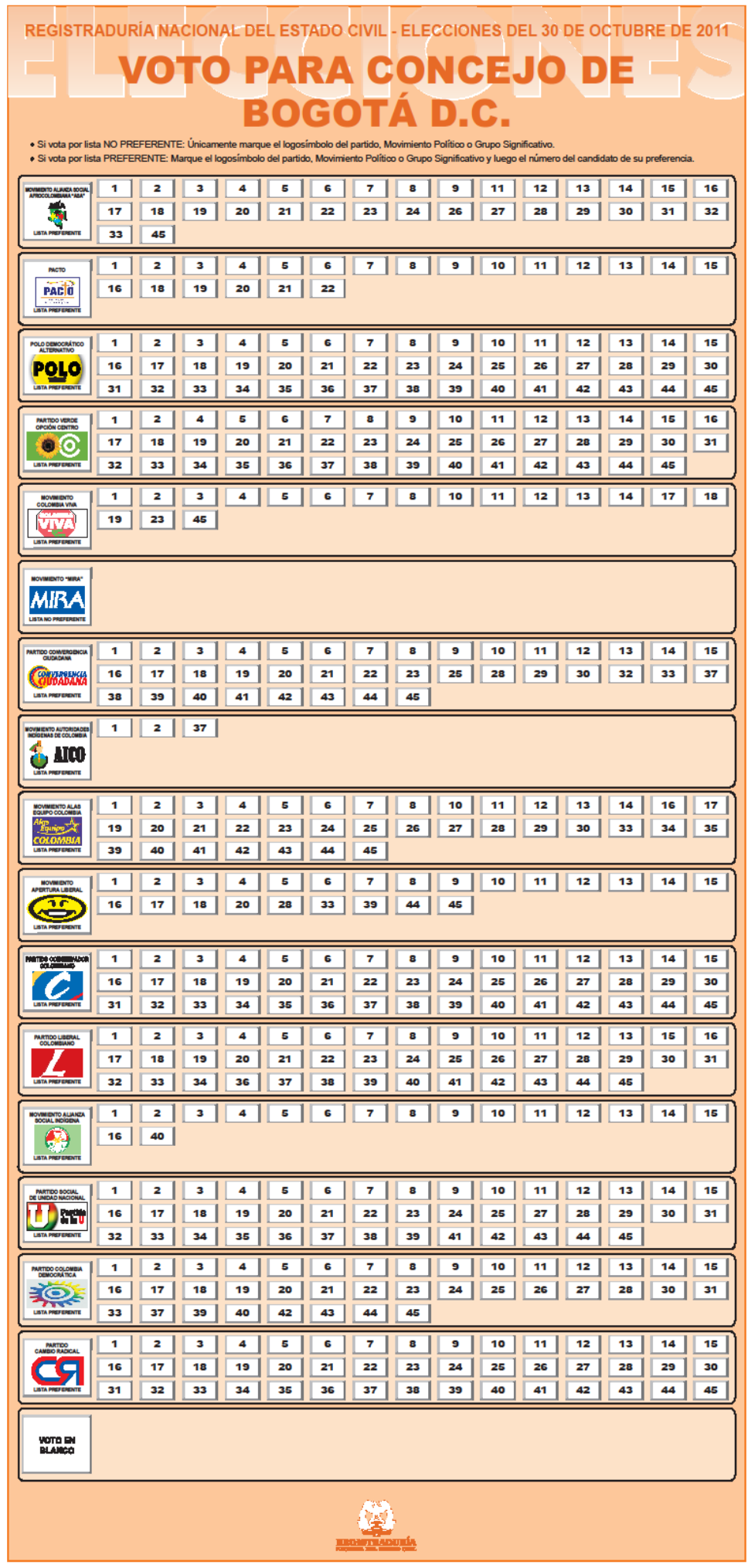

Figure 4a: Third Ballot Design (2011), local elections, Concejo de Bogotá (Used for the simulation) 
Text Figure 4a: To cast a valid vote for candidate \#17 from the Liberal Party, the voter is expected to put a mark over the party logo, and another mark over the number \#17. The voter could also mark only the party logo, or the number of the candidate within the party designated area. 


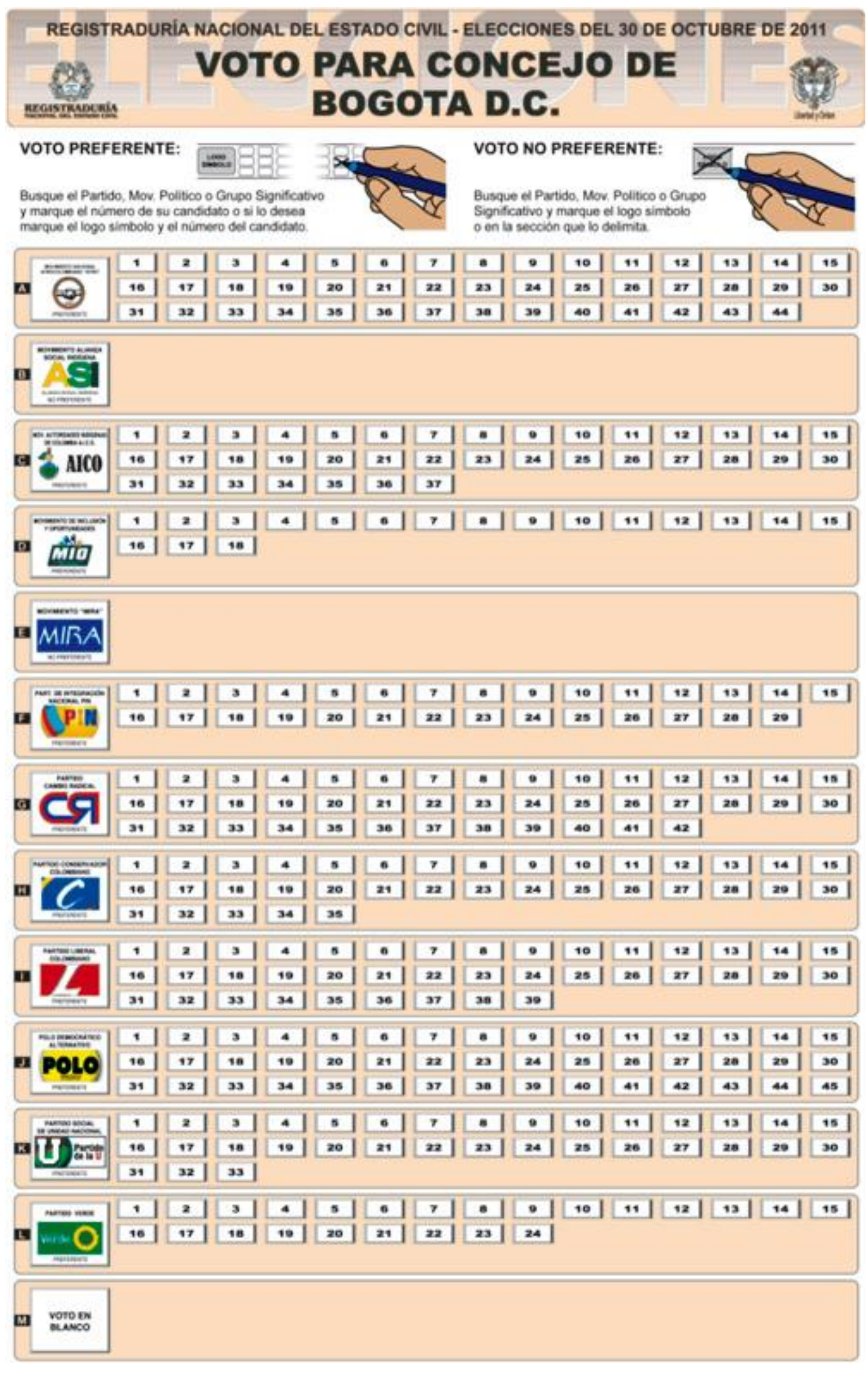

Figure 4b: Third Ballot Design, as used in 2011Text Figure 4b: To cast a valid vote for candidate \#17 from the Liberal Party, the voter is expected to put a mark over the party logo, and another 
mark over the number \#17. The voter could also mark only the party logo, or the number of the candidate within the party designated area. 


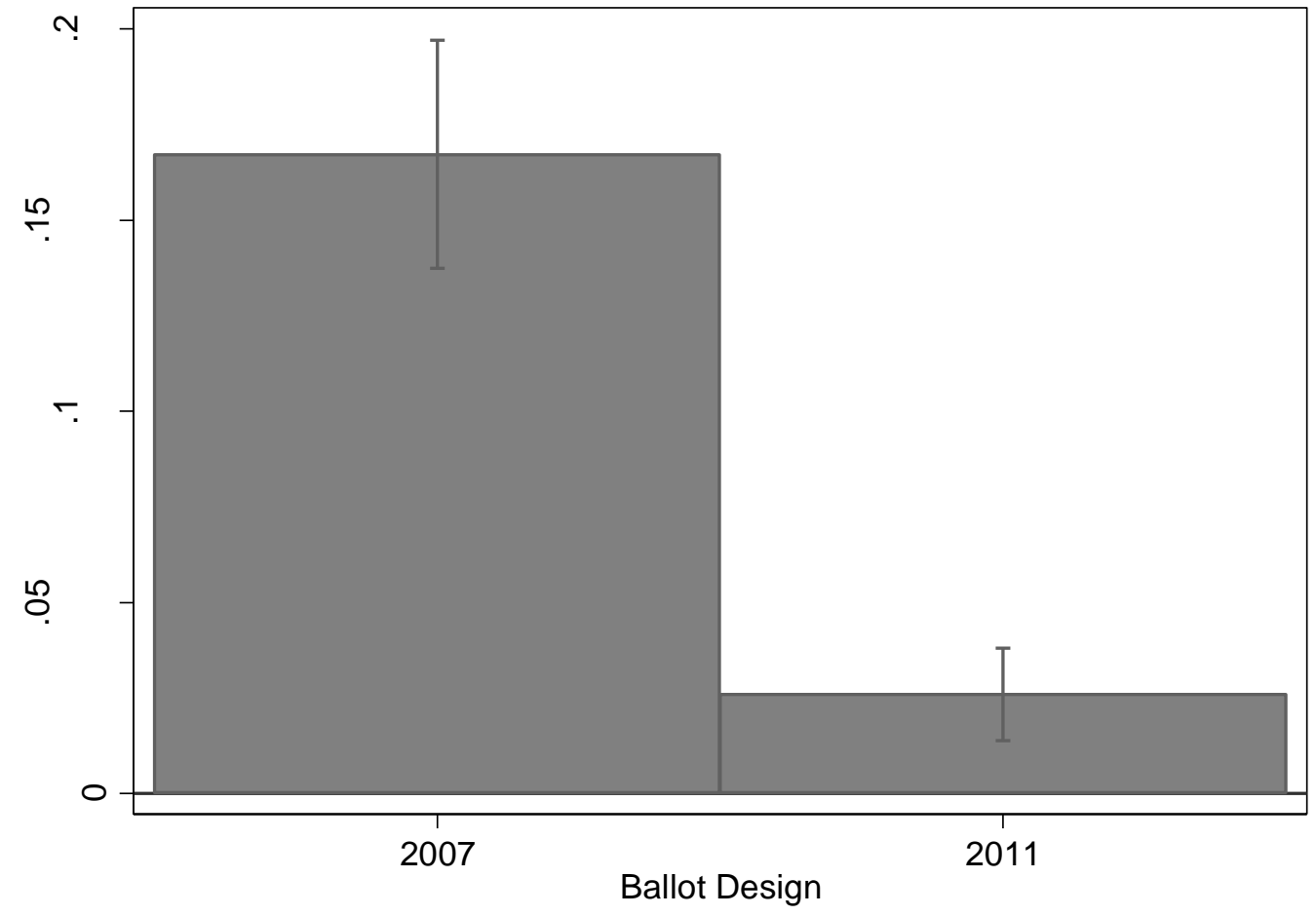

Figure 5: Probability of Spoiling the Ballot, by Ballot Type (2007-2011) 


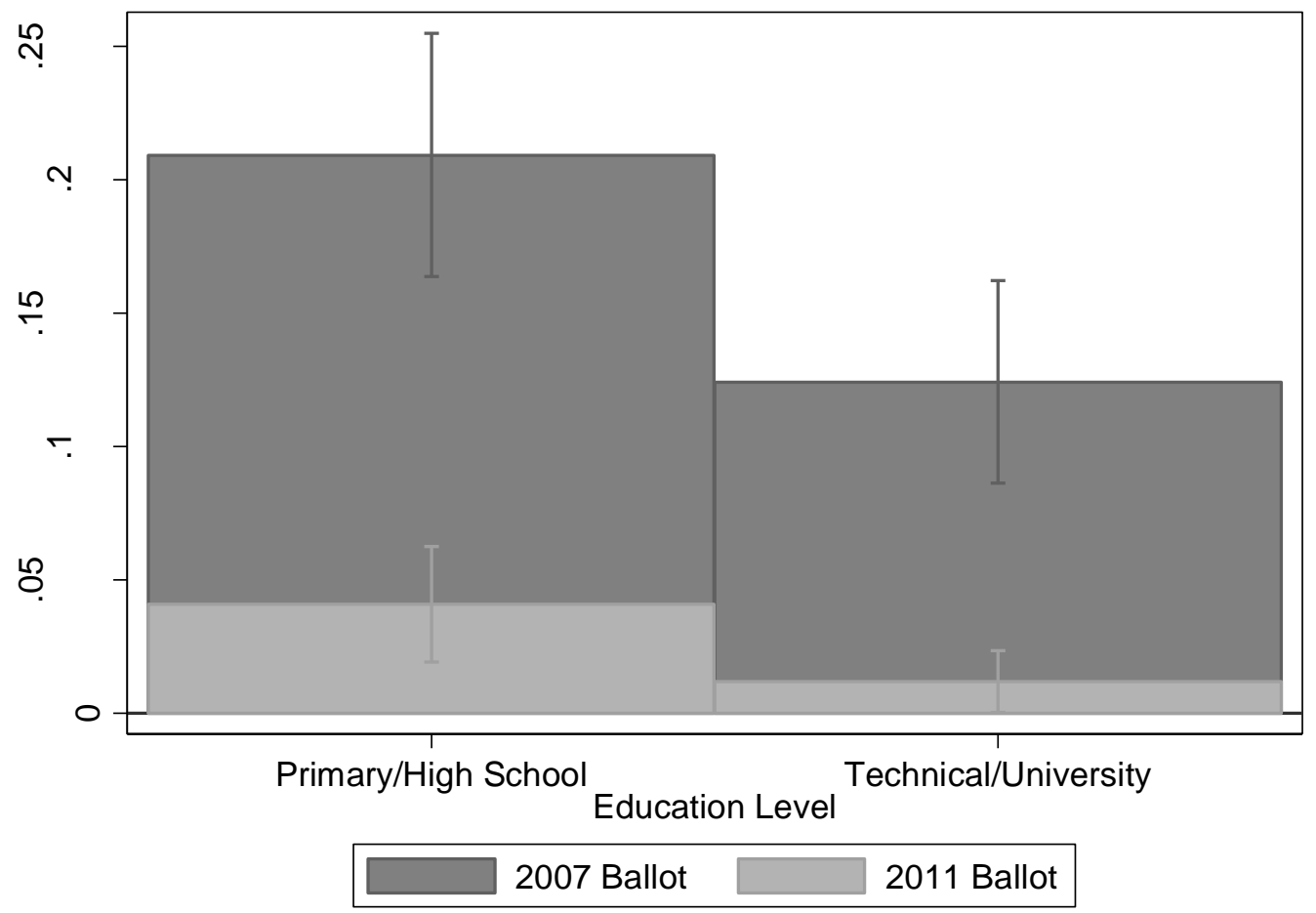

Figure 6: Level of Self-Reported Education and Probability of Spoiling the Ballot, by Ballot Type (2007-2011) 


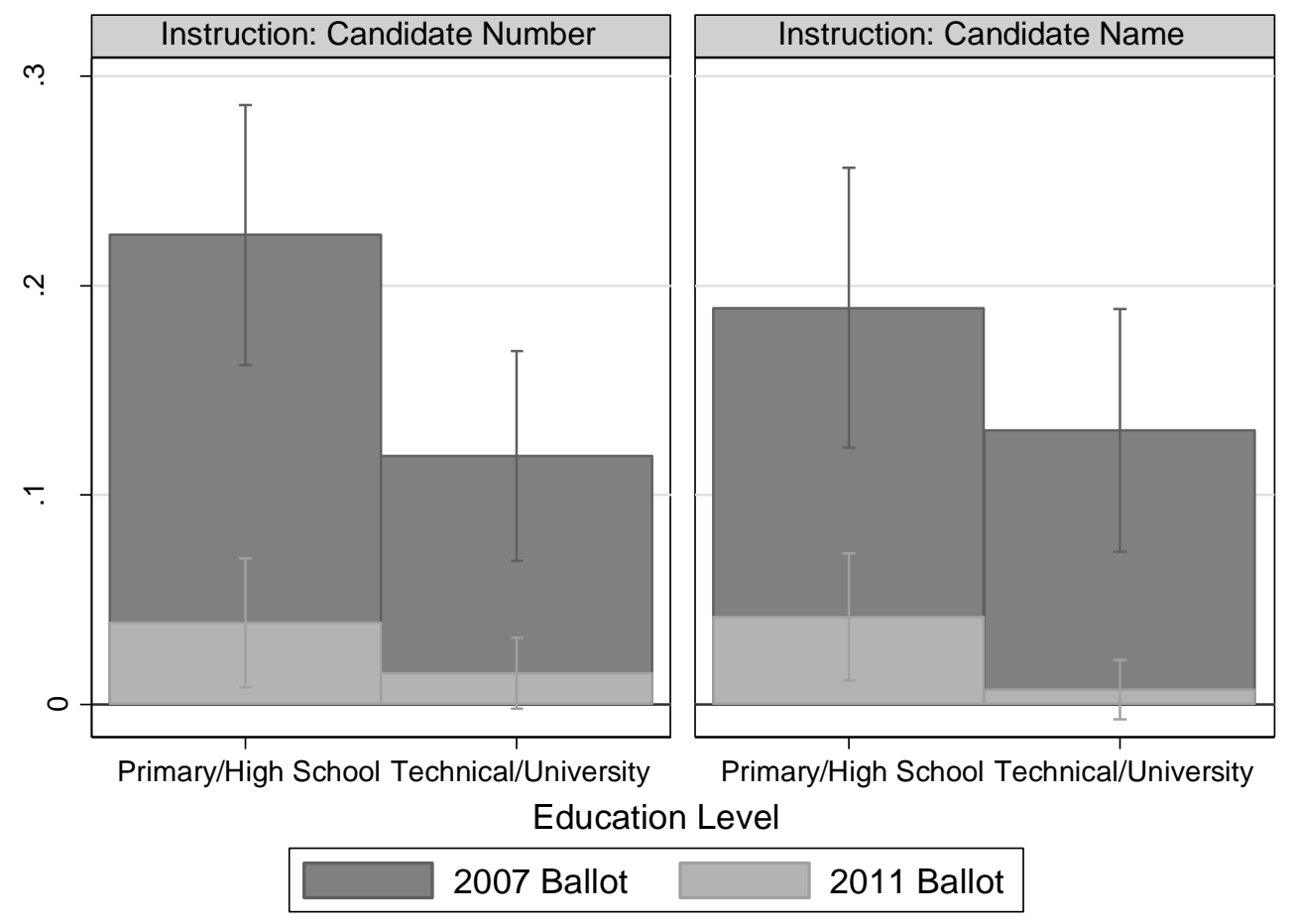

Figure 7: Level of Self-Reported Education and Probability of Spoiling the Ballot per instruction, by Ballot Type (2007-2011) 



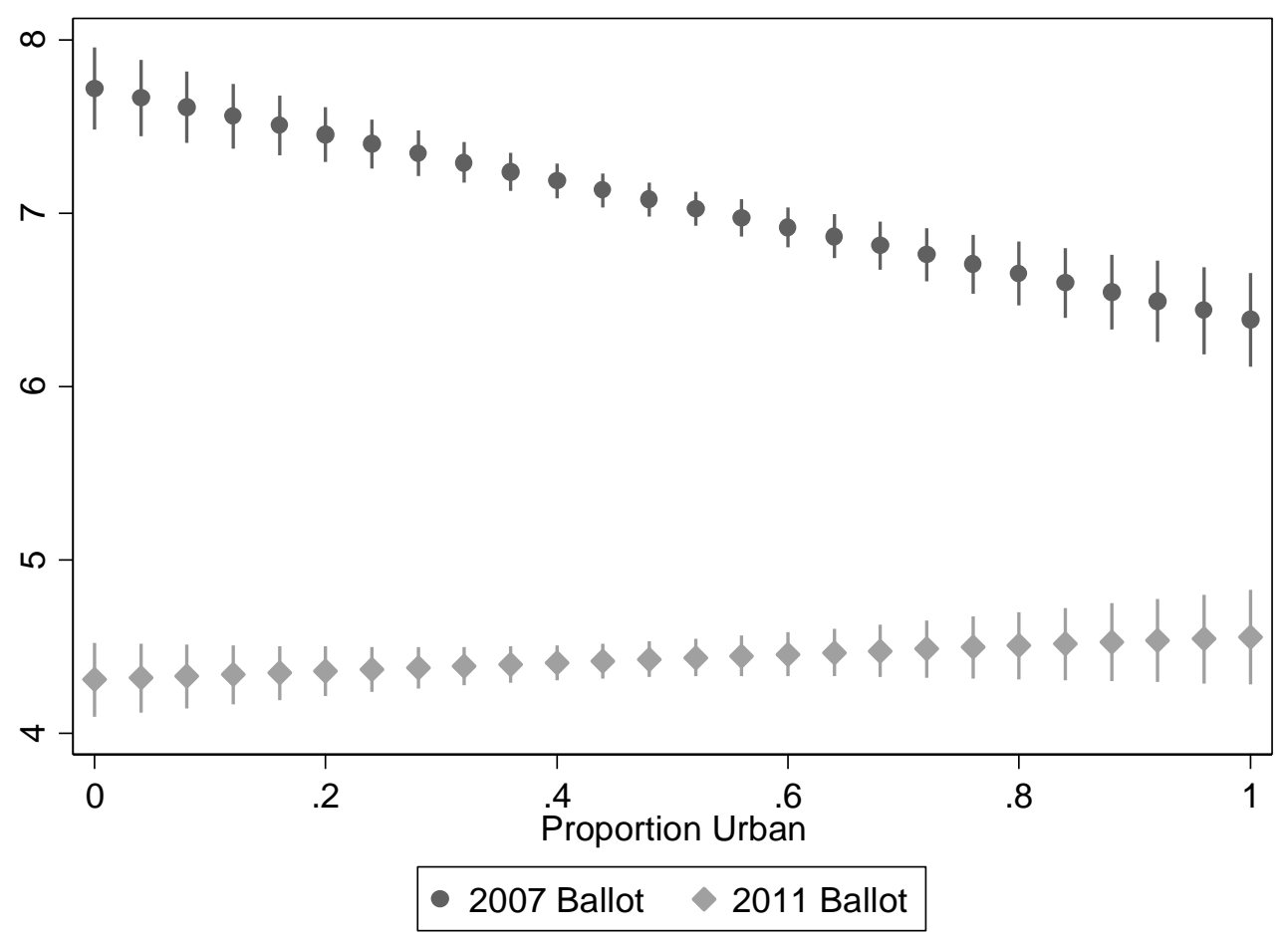

Figure 8: Proportion of Urban Population and the Predicted amount of Invalid Ballots, by Ballot Type (2007-2011) 


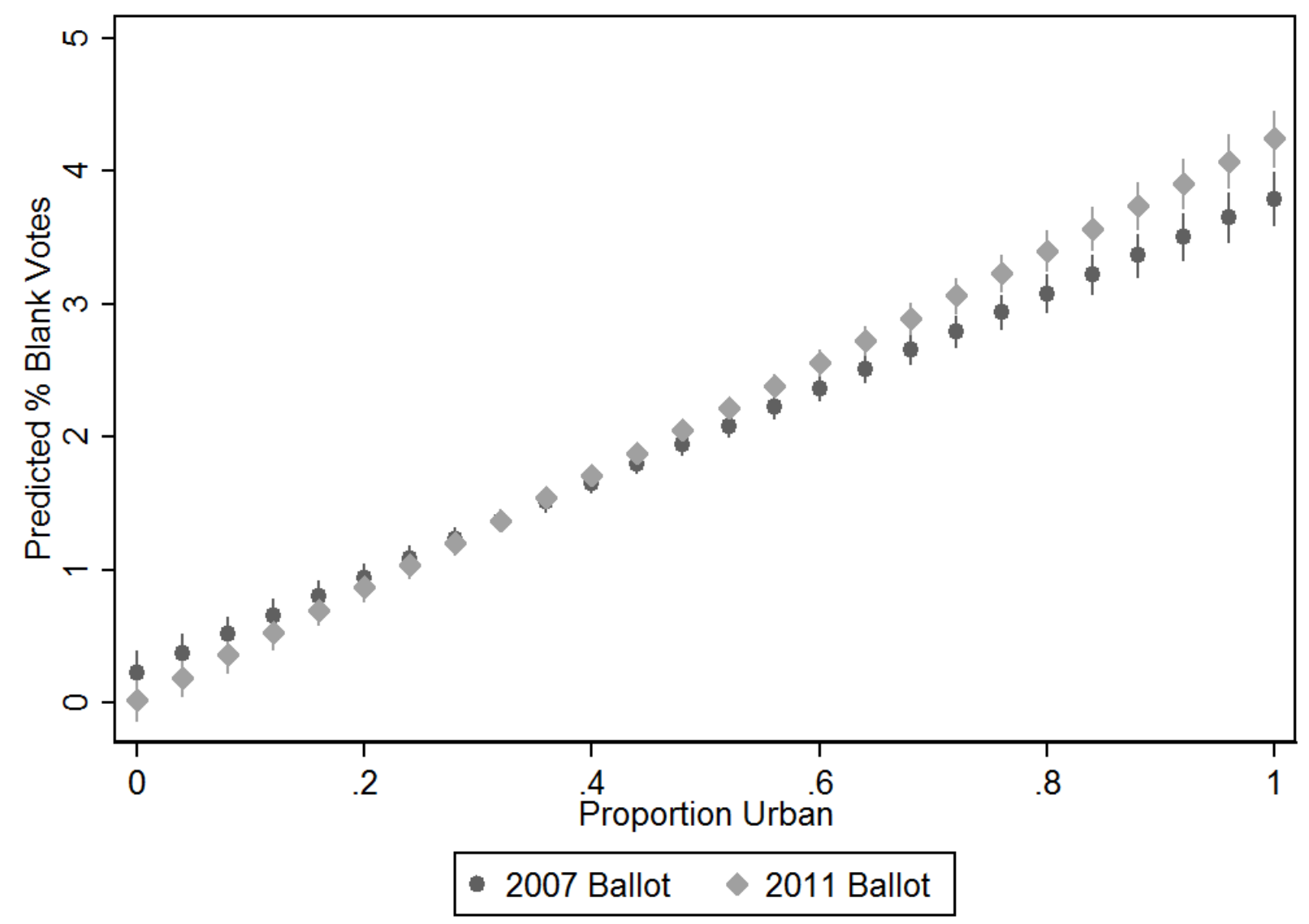

Figure 9: Proportion of Urban Population and the Predicted amount of Blank Ballots, by Ballot Type (2007-2011) 